\title{
PENGARUH PENGGUNAAN MEDIA PEMBELAJARAN POWERPOINT TERHADAP HASIL BELAJAR PESERTA DIDIK MATA PELAJARAN IPS DI KELAS VIII DI SMP NEGERI 2 BELITANG
}

\author{
Leni Marlina', Rafika Rahmadhani ${ }^{2}$, Vovi Sinta ${ }^{3}$ \\ 1,2 Program Studi Pendidikan Ekonomi STKIP Nurul Huda Sukaraja \\ *e-mail: marlinaleni9635@gmail.com
}

\begin{abstract}
Abstrak: Tujuan dari penelitian ini adalah untuk mengetahui pengaruh media pembelajaran powerpoint terhadap hasil belajar peserta didik pada mata pelajaran IPS di kelas VIII. Dalam penelitian ini menggunakan desain Quasi Experimental Design dengan bentuk Nonequivalent Control Group Design. Penelitian menggunakan kelas eksperimen dan kelas kontrol, yang menjadi kelas eksperimen dalam penelitian ini adalah kelas VIII.9 dengan jumlah 32 peserta didik, dan yang menjadi kelas kontrol adalah kelas VIII.10 dengan jumlah 32 peserta didik. Berdasarkan hasil uji deskriptif diperoleh hasil belajar peserta didik dengan kategori sedang sebesar $71,875 \%$. Berdasarkan uji normalitas dan uji homogenitas yang telah dilakukan kedua sampel berdistribusi normal dan homogen. Uji hipotesis, diperoleh kesimpulan terdapat pengaruh penggunaan media pembelajaran powerpoint terhadap hasil belajar peserta didik mata pelajaran IPS di kelas VIII di SMP Negeri 2 Belitang. Hal ini dibuktikan dengan nilai $t_{\text {hitung }} 2,265>t_{\text {tabel }} 1,693$ dengan taraf signifikan $0,031<0,05$ sehingga $\mathrm{H}_{\mathrm{a}}$ diterima dan $\mathrm{H}_{0}$ ditolak.
\end{abstract}

Kata Kunci: Media Pembelajaran PowerPoint, Hasil Belajar

\section{PENDAHULUAN}

Pendidikan adalah investasi sumber daya manusia jangka panjang yang mempunyai nilai strategis bagi kelangsungan peradaban manusia didunia. Pendidikan berasal dari kata "didik", lalu kata ini mendapat awalan me sehingga menjadi "mendidik", artinya memelihara dan memberi latihan. Dalam bahasa Inggris, education (pendidikan) berasal dari kata educate (mendidik) artinya memberi peningkatan (to elicit, to grive rise to), dan mengembangkan (to evolve, to develop). Dalam artian yang sempit, education atau pendidikan berarti perbuatan atau proses perbuatan untuk memperoleh pengetahuan. Dari beberapa pengertian diatas, dapat disimpulkan bahwa education (pendidikan) berarti usaha secara sengaja yang dilakukan oleh orang untuk mencari peningkatan atau pengembangan dalam dirinya dalam hal ilmu pengetahuan dan perilaku yang dibutuhkan.

Pendidikan memiliki peran yang besar dalam meningkatkan kualitas sumber daya manusia. Pendidikan pada setiap jenjang pendidikan melibatkan proses belajar. "Proses belajar merupakan tahapan perubahan perilaku kognitif, afektif, dan 


\section{Pengaruh Penggunaan Media Pembelajaran Powerpoint Terhadap Hasil Belajar Peserta Didik Mata Pelajaran IPS Di Kelas VIII Di SMP Negeri 2 Belitang}

psikomotor yang terjadi dalam diri peserta didik."(Syah dalam Fitriyana, 2019:256), perubahan tersebut bersifat positif dan berorientasi ke arah yang lebih baik dari keadaan sebelumnya.

Perkembangan ilmu pengatahuan dan teknologi semakin mendorong upayaupaya pembaruan dalam pemanfaatan hasil-hasil teknologi dalam proses belajar. Dengan kemajuan teknologi, perkembangan pendidikan semakin lama semakin mengalami perubahan. Pendidikan di sekolah maupun di tingkat perguruan tinggi sekarang ini telah menunjukkan perkembangan pesat pada bidang kurikulum, metodologi, peralatan, dan penilaian. Begitu juga, telah terjadi perubahan pada bidang administrasi, organisasi, personil (SDM), dan supervisi pendidikan. Sekarang ini, pembelajaran mulai disesuaikan dengan perkembangan teknologi, sehingga terjadi perubahan dan pergeseran paradigma pendidikan (Marjito, E.R, 2016:148).

Penggunaan alat-alat, perlengkapan pendidikan, media pendidikan dan pengajaran di sekolah maupun di perguruan tinggi mulai disesuaikan dengan kemajuan. Penggunaan alat-alat bantu mengajar, alat-alat bantu peraga pendidikan, audio, visual, dan audio-visual serta perlengkapan sekolah lainnya disesuaikan dengan perkembangan.

Penggunaan media pembelajaran merupakan salah satu komponen penting di dalam proses pembelajaran di sekolah. Penggunaan media pembelajaran dipandang penting, karena dapat membantu pencapaian tujuan pembelajaran. Oleh karena itu, penyiapan media pembelajaran menjadi salah satu tanggung jawab pendidik (Kurniawati, A, 2011:2-3). Banyak sekali media belajar yang dapat digunakan dalam proses belajar mengajar. Media pembelajaran merupakan salah satu komponen pembelajaran yang mempunyai peranan penting dalam kegiatan proses belajar mengajar. Pemanfaatan media seharusnya merupakan bagian yang harus mendapat perhatian guru dalam setiap kegiatan pembelajaran. Sehingga guru perlu mempelajari bagaimana menetapkan media pembelajaran agar dapat mengefektifkan pencapaian tujuan pembelajaran dalam proses belajar mengajar (Warass, R. D, 2016:2-3).

Salah satu media yang menarik adalah media powerpoint yang merupakan program dari microsoft yang digunakan sebagai perangkat lunak untuk mempresentasikan materi kepada peserta didik di dalam proses pembelajaran serta diharapkan dapat membantu pencapaian tujuan pembelajaran dan peningakatan motivasi belajar peserta didik. Aplikasi powerpoint menyediakan fasilitas slide untuk menampung pokok-pokok pembicaraan yang akan disampaikan pada peserta didik. Dengan fasilitas animasi, suatu slide dapat dimodifikasi dengan menarik.

Begitu juga dengan adanya fasilitas front picture, sound dan effect dapat dipakai untuk membuat slide yang bagus. Bila slide ini disajikan, maka para pendengar dapat tertarik untuk menerima apa yang akan disampaikan. Penerapan media pembelajaran microsoft powerpoint yang sesuai dengan cara dan prinsip yang tepat, akan mencapai beberapa tujuan yang ingin dicapai dalam proses belajar mengajar tersebut, seperti meningkatkan minat belajar sehingga menjadikan peserta didik mendapatkan hasil belajar yang baik.

Media pembelajaran menggunakan microsoft powerpoint ini sudah banyak digunakan oleh para pendidik di SMP maupun SMA atau SMK serta Perguruan 
Tinggi karena microsoft powerpoint dapat menampilkan informasi berupa tulisan, gambar, animasi, serta suara sehingga peserta didik dapat lebih tertarik dalam mengikuti proses pembelajaran.

Salah satu indikator tercapainya tujuan pembelajaran adalah dengan melihat hasil belajar peserta didik. Hasil belajar memiliki kedudukan yang sangat penting dan tidak dapat dipisahkan dari proses pembelajaran. Namun, dalam melakukan kegiatan belajar tidak semua peserta didik memperoleh hasil belajar yang memuaskan karena setiap individu memiliki perkembangan kognitif yang berbeda-beda. Menurut Syah dalam Arumdani, dkk (2018:4), keberhasilan belajar peserta didik dipengaruhi oleh faktor, yaitu faktor internal dan faktor eksternal. Faktor internal adalah segala faktor yang berasal dari dalam diri peserta didik, diantaranya kondisi fisik, tingkat kecerdasan, siukap, bakat, minat, motivasi, dan sebagainya. Sedangkan faktor eksternal adalah segala faktor yang berasal dari luar diri peserta didik diantaranya lingkungan keluarga, masyarakat, pergaulan, sumber belajar, fasilitas belajar, keadaan sosial ekonomi keluarga, dan sebagainya.

Mata pelajaran IPS merupakan salah satu mata pelajaran yang diberikan di Sekolah Menengah Pertama (SMP). Mata pelajaran ini diberikan sebagai mata pelajaran umum dijenjang SMP, yaitu gabungan antara geografi, sejarah, sosiologi, antropologi, ekonomi yang terpadu. Tujuan dari mempelajari mata pelajaran IPS adalah untuk membekali peserta didik yang mana sebagai generasi penerus bangsa Indonesia diharapkan mampu menguasai pengetahuan (knowledge), keterampilan (skills), sikap dan nilai (attitudes and values) yang dapat digunakan untuk memcahkan masalah pribadi atau masalah sosial serta kemampuan mengambil keputusan dan berpartisipasi dalam berbagai kegiatan kemasyarakatan agar menjadi warga negara yang baik.

Memiliki hasil belajar yang tinggi merupakan suatu dambaan bagi setiap orang karena akan menumbuhkan rasa bangga bagi individu baik di sekolah, keluarga, maupun masyarakat. Berdasarkan pengamatan dan pengalaman peneliti pada saat PPL tanggal 16 Oktober - 30 November 2020 di SMP Negeri 2 Belitang, peneliti memasuki kelas VIII.9 dan VIII.10, sebagian besar peserta didik memiliki permasalahan dalam belajar yaitu masih banyak peserta didik yang kurang fokus dalam proses pembelajaran karena dalam proses pembelajaran tersebut kedua kelas tersebut kekurangan sumber belajar berupa buku paket. Apalagi disaat kondisi covid19 yang waktu atau jam mengajarnya dikurangi, hal ini membuat peneliti mengalami sedikit kesulitan untuk memberikan materi ketika praktik mengajar di kedua kelas tersebut karena peneliti harus mencatatkan materi terlebih dahulu lalu menjelaskan materi tersebut kepada mereka, hal tersebut membuat peserta didik menjadi pasif dalam menerima materi ajar dan membuat peserta didik kurang aktif dan kurang bersemangat dalam belajar.

Pada mata pelajaran IPS aktifitas peserta didik sangat diperlukan, karena pelajaran ini tidak hanya dituntut mendengar atau memperhatikan, tetapi dituntut untuk mengaplikasikan materi yang diterimanya, dalam bentuk mengerjakan dan menyelesaiakan soal-soal. Jadi, dalam hal ini peserta didik dituntut lebih aktif dan kreatif. Apabila dalam proses pembelajaran IPS dibuat menyenangkan, dimana penggunaan media pembelajaran yang tepat dan dapat membangkitkan minat serta pemahaman peserta didik pada mata pelajaran IPS, maka peserta didik akan merasa 


\section{Pengaruh Penggunaan Media Pembelajaran Powerpoint Terhadap Hasil Belajar Peserta Didik Mata Pelajaran IPS Di Kelas VIII Di SMP Negeri 2 Belitang}

lebih senang, tidak bosan, dan tidak sulit dalam mengikuti kegiatan pembelajaran. Sehingga tidak ada lagi keluhan tentang kurangnya minat dan rendahnya hasil belajar peserta didik.

Berdasarkan uraian diatas, maka penulis tertarik untuk meneiliti mengenai Pengaruh Penggunaan Media Pembelajaran PowerPoint Terhadap Hasil Belajar Peserta Didik Mata Pelajaran IPS Di Kelas VIII SMP Negeri 2 Belitang.

\section{METODE}

Penelitian ini menggunakan penelitian quasi experimental yaitu dengan nonequivalent control group design. Dalam penelitian ini menggunakan dua kelas yaitu, kelas eksperimen dan kelas kontrol hanya saja pada desain ini kelompok eksperimen dan kelompok kontrol tidak dipilih secara random. Dalam penelitian ini terdapat dua variabel yaitu variabel terikat atau variabel independen dan variabel bebas atau variabel dependen. Variabel independen dalam penelitian ini adalah pengaruh penggunaan media pembelajaran powerpoint, sedangkan variabel dependennya adalaha hasil belajar IPS di kelas VIII di SMP Negeri 2 Belitang.

Populasi dalam penelitian ini adalah seluruh peserta didik kelas VIII di SMP Negeri 2 Belitang yang berjumlah 319 peserta didik. Sampel penelitian ini adalah kelas VIII.9 sebagai kelas eksperimen dan kelas VIII.10 sebagai kelas kontrol. Teknik pengumpulan data yang digunakan adalah test, dan observasi. Uji instrumen dilakukan dengan uji validitas, uji reliabilitas, tingkat kesukaran, dan daya pembeda. Teknik analisis data yang digunakan adalah uji normalitas, uji homogenitas, uji liniear sederhana, dan uji hipotesis.

\section{HASIL DAN PEMBAHASAN}

Hasil

Berdasarkan tujuan penelitian yakni untuk mengetahui presentase pemanfaatan Powerpoint maka dilakukan tes dan penyebaran angket dengan penjabaran sebagai berikut:

Tabel. 1

DESKRIPSI HASIL BELAJAR PESERTA DIDIK

\begin{tabular}{|c|c|c|c|c|c|}
\hline & & $\begin{array}{c}\text { Pretest } \\
\text { Eksperimen }\end{array}$ & $\begin{array}{c}\text { Posttest } \\
\text { Eksperimen }\end{array}$ & Pretest Kontrol & $\begin{array}{l}\text { Postest } \\
\text { Kontrol }\end{array}$ \\
\hline \multirow[t]{4}{*}{$\bar{N}$} & Valid & 32 & 32 & 32 & 32 \\
\hline & Missing & & & & 0 \\
\hline & & 40,31 & 73,59 & 38,91 & 59,38 \\
\hline & & 40,00 & 77,50 & 40,00 & 60,00 \\
\hline
\end{tabular}


Mode Std. Deviation

Minimum

Maximum

40
10,313
25
65

$80^{a}$
18,327
30
100

$35^{a}$
9,733
20
65

21,804

$55^{\mathrm{a}}$

1. Analisis Deskriptif

Berdasarkan tabel diatas dapat disimpulkan bahwa kategori nilai media pembelajaran powerpoint dan hasil belajar peserta didik pada kelas eksperimen sebesar $71,875 \%$ dan kelas kontrol sebesar 65,625\%. Hal ini dinyatakan bahwa media belajar powerpoint dan hasil belajar mata pelajran IPS peserta didik kelas VIII di SMP Negeri 2 Belitang termasuk dalam kategori sedang.

2. Uji Prasyarat Analisis

a. Uji Normalitas

Tabel. 2

\begin{tabular}{|c|c|c|c|c|c|}
\hline & & $\begin{array}{c}\text { Pretest } \\
\text { Eksperim } \\
\text { en }\end{array}$ & $\begin{array}{c}\text { Posttest } \\
\text { Eksperime } \\
n\end{array}$ & $\begin{array}{l}\text { Pretest } \\
\text { Kontrol }\end{array}$ & $\begin{array}{l}\text { Postest } \\
\text { Kontrol }\end{array}$ \\
\hline \multicolumn{2}{|l|}{$\mathrm{N}$} & 32 & 32 & 32 & 32 \\
\hline \multirow{2}{*}{$\begin{array}{l}\text { Normal } \\
\text { Parameters }\end{array}$} & Mean & 40,31 & 73,59 & 38,91 & 59,38 \\
\hline & $\begin{array}{l}\text { Std. } \\
\text { Deviation }\end{array}$ & 10,313 & 18,327 & 9,733 & 21,804 \\
\hline \multirow{3}{*}{$\begin{array}{l}\text { Most Extreme } \\
\text { Differences }\end{array}$} & Absolute &, 137 & , 137 & , 143 & ,115 \\
\hline & Positive &, 137 & 090 & 143 & ,099 \\
\hline & Negative &,- 082 &,- 137 &,- 094 &,- 115 \\
\hline \multicolumn{2}{|l|}{ Test Statistic } &, 137 &, 137 & , 143 &, 115 \\
\hline \multicolumn{2}{|c|}{ Asymp. Sig. (2-tailed) } &, $132^{\mathrm{c}}$ &, $135^{\mathrm{c}}$ &, $096^{\mathrm{c}}$ &, $200^{\mathrm{c}, \mathrm{d}}$ \\
\hline
\end{tabular}

a. Test distribution is Normal.

b. Calculated from data.

í. Lilliefors Significance Correction.

a d. This is a lower bound of the true significance.

as menunjukkan bahwa data tersebut berdistribusi normal karena nilai signifikansinya > 0,05.

b. ji Homogenitas

Tabel. 3

Test of Homogeneity of

Variances

Hasil Belajar Peserta Didik

\begin{tabular}{|l|l|l|l|}
\hline Levene & & & \\
Statistic & $\mathrm{df1}$ & $\mathrm{df2}$ & Sig. \\
$\mathbf{4 0}$
\end{tabular}




\section{Pengaruh Penggunaan Media Pembelajaran Powerpoint Terhadap Hasil Belajar Peserta Didik Mata Pelajaran IPS Di Kelas VIII Di SMP Negeri 2 Belitang}

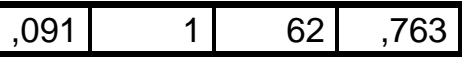

Berdasarkan tabel diatas dapat disimpulkan bahwa hasil pre-test maupun post test pada kelas kontrol dan kelas eksperimen adalah homogen karena nilai signifikansinya $<0,05$.

c. Uji Liniear Sederhana

Tabel. 5

Model Summary

\begin{tabular}{|l|r|r|r|r|}
\hline Model & $\mathrm{R}$ & R Square & $\begin{array}{c}\text { Adjusted R } \\
\text { Square }\end{array}$ & $\begin{array}{c}\text { Std. Error of } \\
\text { the Estimate }\end{array}$ \\
\hline 1 &, $382^{\mathrm{a}}$ &, 146 &, 118 & 17,215 \\
\hline
\end{tabular}

a. Predictors: (Constant), Hasil Belajar Peserta Didik Kelas Eksperimen (Pre)

Hasil dari analisis uji regresi liniear sederhana pada kelas kontrol dapat dilihat pada output model summary yang diperoleh $\mathrm{R}$ square sebesar 0,146 , $R$ square dapat disebut koefisien diterminasi yang dalam hal ini berarti $0,146 \times 100 \%=14,6 \%$ terdapat pengaruh antara variabel pengaruh penggunaan media pembelajaran powerpoint terhadap hasil belajar peserta didik mata pelajaran IPS, sedangkan $85,4 \%$ dipengaruhi oleh faktor lainnya yang tidak diteliti dalam penelitian ini.

d. Uji Hipotesis

Hasil pengujian statistik pada aplikasi spss 22 diperoleh $t_{\text {hitung }}$ 2,265 > $t_{\text {tabel }} 1,693$ yang berarti $H_{a}$ diterima dan $H_{0}$ ditolak dengan taraf signifikan 0,031 $<0,05$ sehingga terdapat pengaruh penggunaan media pembelajaran powerpoint terhadap hasil belajar peserta didik mata pelajaran IPS di kelas VIII di SMP Negeri 2 Belitang. 


\section{Pembahasan}

Berdasarkan analisis deskriptif hasil belajar peserta didik pada kelas kontrol dan kelas eksperimen terdapat hasil yang cukup berbeda. Untuk kelas kontrol terdapat 21 peserta didik yang memiliki hasil belajar dengan kategori sedang sebesar $65,625 \%$. Sedangkan untuk kelas eksperimen terdapat 23 peserta didik yang memiliki hasil belajar dengan kategori sedang sebesar $71,875 \%$. Skor rata-rata pretest kelas kontrol diperoleh sebesar 38,91 , pada kelas post test kontrol diperoleh rata-rata 59,38. Pada kelas pre-test eksperimen diperoleh rata-rata 40,31 namun setelah diberi perlakuan (post test) untuk rata-rata post test kelas eksperimen diperoleh 73,59. Pada kedua kelas ini sama-sama mengalami peningkatan namun pada kelas eksperimen peningkatannya lebih besar.

Berdasarkan hasil uji regresi liniear sederhana diperoleh hasil $\mathrm{R}$ Square sebesar 0,146 yang berarti pengaruh penggunaan media pembelajaran powerpoint terhadap hasil belajar adalah $0,146 \times 100 \%=14,6 \%$ dan sisanya $85,4 \%$ dipengaruhi oleh faktor lainnya yang tidak diteliti dalam penelitian ini.

Hasil dari uji hipotesis (uji t) diperoleh $t_{\text {hitung }} 2,265>t_{\text {tabel }} 1,693$ yang berarti $H_{a}$ diterima dan $\mathrm{H}_{0}$ ditolak dengan taraf signifikan $0,031<0,05$ sehingga terdapat pengaruh penggunaan media pembelajaran powerpoint terhadap hasil belajar peserta didik mata pelajaran IPS di kelas VIII di SMP Negeri 2 Belitang.

\section{SIMPULAN}

Dari hasil penelitian mengenai penggunaan media powerpoint terhadap hasil belajar peserta didik kelas VIII di SMP Negeri 2 Belitang, dapat diambil kesimpulan antara lain:

Penggunaan media powerpoint yang diterapkan di SMP Negeri 2 Belitang sudah cukup baik hal ini dapat dibuktikan dengan hasil belajar pada kelas eksperimen setelah diberi perlakuan dengan diterapkan media powerpoint berkategori sedang (71,875\%). Hasil belajar peserta didik pada mata pelajaran IPS kelas VIII di SMP Negeri 2 Belitang setelah diterapkan media powerpoint berkategori sedang $(71,875 \%)$. Ada pengaruh yang signifikan antara penggunaan media powerpoint terhadap hasil belajar peserta didik mata pelajaran IPS di kelas VIII di SMP Negeri 2 Belitang berdasarkan pada pengujian hipotesis menggunakan uji t dengan SPSS 22, didapat nilai $t_{\text {hitung }} 2,265>t_{\text {tabel }} 1,693$ yang berarti $\mathrm{H}_{\mathrm{a}}$ diterima dan $\mathrm{H}_{0}$ ditolak dengan taraf signifikan 0,031<0,05.

\section{SARAN}

Untuk guru, diharapkan kepada guru untuk dapat memanfaatkan powerpoint sebagai media untuk mengajar dengan memilih materi yang cocok dengan media ini. Untuk sekolah, bagi pihak sekolah diharapkan agar selanjutnya dalam pembagian sumber belajar berupa buku paket lebih dioptimalkan lagi supaya tidak ada lagi kelaskelas yang kekurangan sumber belajar berupa buku paket. Untuk peserta didik, agar lebih aktif dan semangat lagi dalam belajar. Untuk peneliti selanjutnya, diharapkan dapat melakukan penelitian berkelanjutan dengan media yang lain dengan judul yang sama atau bisa dengan menambah variabel minat, motivasi, dan lain sebagainya. 


\section{Pengaruh Penggunaan Media Pembelajaran Powerpoint Terhadap Hasil Belajar Peserta Didik Mata Pelajaran IPS Di Kelas VIII Di SMP Negeri 2 Belitang}

\section{UCAPAN TERIMAKASIH}

Ucapan terimakasih ditujukan kepada STKIP Nurul Huda yang menjadi bagian perjalanan menempuh pendidikan Sarjana Pendidikan Ekonomi dan juga kepada seluruh pihak yang telah membantu dalam pembuatan skripsi penulis. Kepada SMP Negeri 2 Belitang yang menjadi tempat penelitian, kedua orang tua dan kedua pembimbing penulis, teman seperjuangan yang telah memberikan dorongan dan kebersamaan yang tidak terlupakan, serta terimakasih Tim Jurnal Utility STKIP Nurul Huda.

\section{REFERENSI}

Anisah, A. (2017). Pengaruh penggunaan buku teks pelajaran dan internet sebagai sumber belajar terhadap hasil belajar siswa pada pembelajaran IPS. Logika Jurnal IImiah Lemlit Unswagati Cirebon, 18(3), 1-18.

Aryani, T. (2017). Pengaruh Ketertarikan Siswa Pada Media Pembelajaran Tamplate Powerpoint Terhadap Keterampilan Berpresentasi (Studi Pada Pelajaran Ekonomi Materi Koperasi Kelas X IPS 2 di SMA Negeri 16 Bandung) (Doctoral dissertation, FKIP Unpas).

Juwita, G. R. (2012). Pengaruh Penggunaan Microsoft Powerpoint terhadap Minat dan Hasil Belajar Matematika Peserta Didik pada Materi Segitiga dan Segiempat (Studi Eksperimen terhadap Peserta Didik Kelas VII SMP Negeri 1 Rancah Kabupaten Ciamis Tahun Pelajaran 2011/2012) (Doctoral dissertation, IAIN Syekh Nurjati Cirebon).

Marjito, E. R. (2016). Pengaruh Penggunaan Power Point Terhadap Kemampuan Berpikir Kritis Mahasiswa Pada Mata Kuliah Sejarah Kemerdekaan Indonesia Di Program Studi Pendidikan Sejarah Ikip Pgri Pontianak. Sosial Horizon: Jurnal Pendidikan Sosial, 2(2), 146-157.

Rochmawati, H. (2017). Pengaruh Media Powerpoint Dalam Pembelajaran Matematikaterhadap Hasil Belajar Matematika Materi Bangun Datar Kelas Vii Smpn 1 Kalidawir Tulungagung Tahun Ajaran 2016/2017.

Simanullang, W. (2019). Pengaruh Pemanfaatan Fasilitas Belajar Terhadap Hasil Belajar Akuntansi Siswa Kelas Xi Di Smk Sinar Husni Helvetia Medan Tahun Pelajaran 2019/2020 (Doctoral dissertation).

Sugiyono. (2016). Metode Penelitian Kuantitatif, Kualitatif, dan R\&D. Bandung: Alfabeta.

Sulastri, S. (2017). Efektivitas Penggunaan Media Power Point Dalam Pembelajaran Pai Di Smp Tunas Dharma Way Galih Lampung Selatan Tahun Ajaran 2016/2017 (Doctoral dissertation, IAIN Raden Intan Lampung).

Trisnawan, I. (2012). Pengembangan Media Pembelajaran Menggunakan Microsoft PowerPoint Pada Mata Pelajaran Pengukuran Dasar Siswa Kelas X di SMK Ma'arif Salam Magelang. Universitas Negeri Yogyakara. 
Leni Marlina1, Rafika Rahmadhani2, Vovi Sinta3

Warass, R. D. (2016). Pengaruh Media Pembelajaran Microsoft Powerpoint Terhadap Hasil Belajar Siswa Pada Mata Pelajaran Akuntansi Kelas XI SMA Pasundan 2 Kota CIMAHI (Doctoral dissertation, FKIP UNPAS). 